\title{
Student Views Related to the Science Fest Actualized in High School History Lessons (The Case of Turkey)
}

\author{
Kadir Ulusoy \\ Correspondence: Kadir Ulusoy, Assoc. Prof. Dr., Education Faculty, Mersin University, Mersin, Turkey.
}

Received: August 22, 2016

doi:10.11114/jets.v4i11.1898

\author{
Accepted: September 7, 2016 \\ Online Published: September 26, 2016 \\ URL: http://dx.doi.org/10.11114/jets.v4i11.1898
}

\begin{abstract}
Rapid changes and developments in education have also changed the content and the scope of the activities carried out in schools. Learning and teaching through experiencing and practicing process carried out after the transition to the constructivist approach in recent years has started and expedited the performance of new activities in several institutions and organizations including both Ministry of National Education and TUBITAK, as the leading, in Turkey. Holding science fests during the educational process has led the observation of the developments in students' cognitive academic competence and psycho-motor levels and encouragement of students' participation into the activities especially with TUBITAK's starting to support. This research especially aimed to determine the situations of the students on project-based thinking skills related to science fests and science fest process supported by TUBITAK within the scope of the history lesson in recent years. The answer was sought to the question of "Do the science fests held in high school history lessons affect project-based thinking of the students?" The research was a descriptive study revealing the contribution of science fests activities performed in history lessons upon the project-based learning of high school students. Qualitative and quantitative data were obtained in the research. This study was limited with 66 participants from the $10^{\text {th }}$ and $11^{\text {th }}$ grade of three different high schools in central districts of Mersin province in 2014-2015 academic year. According to the data obtained at the end of the study, science fests were noticed to provide a clear contribution. In project-based studies, the students were determined to express themselves more easily and get rid of memorizing. Furthermore, it was also noted that visual materials, tools and equipment and three-dimensional materials were expected to be exhibited in science fests. In this study, it was determined that the projects students carried out within the scope of science fests held in the high school history lessons had effect upon the learning awareness of the students.
\end{abstract}

Keywords: history lesson, science fest, project-based learning, student views

\section{Introduction}

The rapid improvements in science and technology in today's world have turned our world into a small residential area. Dizzying improvements occurred as result of innovations' in science and technology triggering each other. This rapid change in science and technology has led the change in definition of qualified individual today's society needs. This change necessitates redetermination of the course content and the task of the history lesson in raising qualified individuals. A big information explosion has occurred through the effect of improving technology in today's world that is also called the "Information Age," the information increasing incrementally every year has been understood to be a great power, and access to information has facilitated. A significant learning in history lesson should be fulfilled in learning environments where pre-knowledge of the students is controlled, the contexts encountered in real life are regarded, the students are active always as mentally and mostly physically, and conceptual change is provided. Furthermore, these learning environments are required to provide opportunities for the students in order to make them enhance the recently learned concept.

In information age when the changes are experienced rapidly in parallel to the improvements in science and technology, the individuals are evaluated according to their knowledge capacity they have and their level of using the knowledge. As mentioned by Caliskan and Turan (2008), increase at need for the creative, qualified and productive individuals who have learned the ways of reaching to the information, are open to change, have developed communication skills, are inclined to teamwork, are able to solve problems caused the appearance of new approaches in education. In recent years, "High School Students Entrepreneurship and Innovation Competitions" have been organized in order to provide the secondary education students to have innovation-based thinking skills by TUBITAK in Turkey. The purpose of these 
competitions is to make contributions upon raising a generation placing the innovation at the center of the entrepreneurship process and so to increase the awareness on innovation and entrepreneurship. It is possible to notice in such implementations that several innovative ideas related to the history lesson have been revealed, and therefore science fests have been organized. As in several fields, the ability of producing, developing and spreading the information in education has recently been studied. In our country, studies and projects on innovation and science fests have been carried out in secondary education through the support of TUBITAK. So that developing the technological abilities of the young who will be in important positions of the country in the future and to create a sustainable education depending upon new design and technologic abilities will be essential.

In today's world when the world is continuously changing, the technology is improving and the information is rapidly consumed, the term of innovation that expresses the renewals has become a part of our lives as providing social and economic benefits. In order to keep up with the time, it is essential to carry out innovations in education as well as all other areas. Innovation in education should aim to provide social benefit raising brain power with a broad world perspective and high academic self-concept participating into teamwork and thinking more creative and critical (Kavacik, 2012). Students' being successful at a multiple-choice test related to the historical research processes does not mean that these students will also be successful when asked to make a research on a subject on history or will be able to correctly use the processes assumed to be known. The most efficient way of observing whether a student can fulfill carrying out a research on history or not is to make student carry out the research. However, it should be noted that using a performance based assessment approach does not mean assessment and measurement tools of a traditional assessment approach will not be used. Optimum assessment of student development and progress is possible through the use of both approaches (performance-based and traditional) together in a balanced way. Performance tasks can be organized as individually or in group assessments. What kind of a performance task will be used can be determined depending upon the level of grade, opportunities of the school (environmental opportunities, number of students in a classroom, etc.), and the way of lecturing. Performance tasks included into the curriculum are provided as samples. Teachers can use these samples as they are or restructure them depending upon the conditions mentioned above. The activities such as creative performances (exhibition, magazine, newspaper, board, history lane, modeling, role playing, etc.), written tasks (research report, article, composition, answering open-ended questions, projects, etc.), presentations, out-class activities (collecting information on the subject, text reading, interviewing, preparing the materials to be used for the activity, etc.) can be stated as the samples of performance tasks (Ministry of National Education, MNE, 2007; 11-12). When the reports of Commission of the European Communities (2005a) and Commission of the European Communities (2005b) were analyzed, it could be noticed that significant goals were set on innovation, information, science and science politics, and sensitivity on implementation of these goals has been displayed in European Union countries and European Union member countries.

\section{What are the Benefits of Science Fests?}

1. Science fests provide students to be recognized and orient them in accordance with their abilities.

2. Because the students will carry out all the studies during the competition through scientific study logic, they know, adapt, care and trust this method.

3. The students comprehend other projects in competition beside the project they carry out in a staggeringly short time, find the mistakes, and make efforts to develop the project to be better. And this creates ambition and an amazing learning environment.

4. Students learn the models and running processes of the devices used in daily life. So that students use devices productively, develop these and understand that each device runs through a simple logic.

5. A positive communication is established between families and students through counseling teachers' participating the families into the project studies. It enhances parent-student-teacher communication. The students who participated into the competition become the source of pride for their families.

6. Science fests provide students to acquire the feeling of achieving and concluding something. This encourages students for the all activities to be carried out and gives confidence.

7. Science fests create a perfect learning environment for the students visiting the carried out projects, and create the feeling of managing the same project on their own in students.

8. Projects emphasize the importance of competition in science and technology through the feelings of students (www.fenokulu.net)

\section{Project-based learning}

Today, individuals have been expected to produce information rather than consuming. Individuals assumed by the 
modern world are the ones who actively participate into the process of creating the meaning through interpreting the information, not the ones who accepts the information as it is and waiting for it to be structured and directed. In student-centered education approach, teaching methods helping students to learn the information in a way that is more active and permanent and far from memorizing are needed. If a learning method at a quality satisfying the needs of students considering their mental skills, interests and abilities is chosen, students are noticed to be more active, participative and keen on learning more permanent information during the learning process (Bayram \& Seloni, 2009). In structured environment that has recently been implemented, teachers should present choices appropriate to the individual differences of students, provide instructions and help students to make their own decision. Teachers are expected to make efforts to provide students solve their own problems instead of intervening into the problem in order to solve. The teachers are also assumed to help students on noticing and correcting the mistakes instead of indicating clearly and immediately (Ayan, 2012). According to Liu, et. al. (2009) letting students express themselves explicitly and question the new materials is essential in terms of revealing the creative energy of students. For that reason, traditional classroom order should be abandoned and a classroom environment in which active learning methods and new approaches are used should be prepared. During this process, carrying out project-based studies is very important.

According to Helle et al. (2006), one of the most significant properties of project-based learning is learning process' being under the control of students, and so students' deciding and directing the learning activities.

In project-based learning;

1. Inter-disciplinary study is required.

2. Students

a. decide themselves on the studies to be carried out,

b. can study within the framework of their own interests and abilities depending upon cooperation taking on responsibility individually and in groups,

c. collect information depending upon the research, and organize the obtained information,

d. observe continuously, and make assessments,

e. present and exhibit what they carry out regularly.

3. Teachers have a role orientating the students and facilitating the studies.

4. The studies conclude with realistic products or presentations; for that reason, "Project-Based Learning" can integrate several different approaches in itself (Demirhan, 2002).

In project-based learning, the subjects are related to the real life. In this sense, because the projects are related to the real life and students reach to information through their own efforts, learning in this model is possible to be mentioned as original and valuable (Ozden, Aydın, Erdem \& Ekmekci, 2009). Ozden, Aydın, Erdem \& Ekmekci (2009) noticed that there were teachers with negative views beside the ones with positive views upon project-based education, and determined that negative views focused especially upon the items related to planning and conducting of the project. Some of the teachers mentioned that a big source of finance was required for the projects, finalization of the project took a long time, difficulties were possible to be experienced in finding an appropriate subject for the project, and management and conduction of a project was hard.

\section{Purpose}

This research especially determined the project-based thinking skills of the students related to the science fests and science fest processes that have recently been supported by TUBITAK within the scope of history lesson. As result of the final curriculum changes, the students carrying out activities in history lesson in accordance with the principles of the constructivist approach has been provided to be aware of scientific process skills. In literature review, noticing no adequate studies upon science fests within the scope of history lesson revealed the goal of this study as overcoming a deficiency in education. An answer was sought to the question of "Do science fests carried out in high school history lessons have an effect upon project-based thinking of the students?

\section{Method}

The research was a descriptive study revealing the contribution of science fest activities performed in history lessons of high school students upon the project-based learning. In the research, qualitative and quantitative several data were obtained. This research aiming to determine the creating of innovational awareness related to history lessons in science fests was designed on screening model. Screening model aims to describe a past or current situation as it is. Individuals or institutions are tried to be described as they are in their own conditions, no effort upon changing and affecting is made (Karasar, 2009). Screening model is a model providing opportunities for using qualitative and quantitative 
research methods together. This study was limited with 66 students who participated into the students from the $10^{\text {th }}$ and $11^{\text {th }}$ grade of three different high schools in central districts of Mersin province in 2014-2015 academic year. Distribution of the students included into the study group according to gender was as 35 (53\%) female students and 31 (47\%) male students. Distribution of the students in the study group according to the level of grade was as 29 (44\%) $10^{\text {th }}$ grade students and $37(56 \%) 11^{\text {th }}$ grade students. The distribution of schools and students included into the study group was as 27 (41\%) participants from Mersin Anatolian High School, 20 (30\%) participants from İçel Anatolian High School, and 19 (29\%) participants from Pakize Kokulu Anatolian High School.

\subsection{Data Collection Tools}

Open-ended question is the type of question in which individuals can easily mention their thoughts on research topic, there is no prediction possible for the answers, and possible answers are not mentioned. In open-ended questions, individuals can deeply explain the research question in accordance with their own thoughts (Metin, 2014, 166). Open-ended question provide opportunities for the individuals to answer without limits. Open-ended questions also provide opportunities for individuals to write their own answers. They encourage reference individuals more rather than the close-ended questions, and participants can write more comprehensive and detailed information (Balci, 2005; Buyukozturk et al., 2011). In the research, 15 questions were prepared in order to receive opinions of the students related to individual innovation and science fests. Subsequently, number of questions was decreased to 11 asking for the opinions of 2 Research Assistants, 2 Assistant Professor Doctors, and 3 Associate Professor Doctors. Upon this, open-ended question forms including 11 questions were handed out to totally 66 students in three different high schools.

\subsection{Data Analysis}

Content analysis method was used for the analysis of the data obtained from the open-ended question forms performed to the students. Content analysis provides the analysis of obtained data in details, and revealing of themes and dimensions that cannot be determined before (Karasar, 2009; Yildirim and Simsek, 2008). For this analysis, it is necessary to conceptualize the data collected previously, to organize the data according to the concepts logically, and to determine the themes explaining the data. In fact, the process in content analysis is to gather data similar to each other under specific concepts and themes, to organize and in a way the reading individuals can easily understand. The process steps required to be carried out during the content analysis were presented below (Yildirim and Simsek, 2008; 227-228).

1. Coding of data

2. Finding the themes

3. Organizing the codes and themes

4. Interpreting the findings

In order to determine coding reliability, an expert from educational sciences department read the data forms within the scope of the research, and coded the relevant theme in the coding list. After filling in the coding list for all data, consistency of the coding list was compared. In this stage, the researchers are required to code the same data set, compare the coding similarities and differences numerically, and reach up to at least 0.70 coding percentage (Yildirim and Simsek, 2008; 233).

In this study, as well, reliability formula of Miles and Huberman (1994) given below was benefited in order to control the reliability of qualitative data analysis.

Reliability = Agreement $/$ (Agreement + Disagreement $)$

Using this formula, fit index accepted as the reliability of the research was calculated as average 0.86 for the open-ended questions. This result also indicated the codes of the researchers as reliable.

\section{Findings}

In this section, the answers given to the open-ended questions were presented. Key expressions in answers of the students and their frequencies were also mentioned.

\section{$1^{\text {st }}$ Question: What do you understand from the concept of science fest?}

Key expressions and frequency values of the $1^{\text {st }}$ question were as below:

Project (29), Scientific study (24), Discovery (17), Invention (7), Creative (5), New ideas(5), Experiment (4), Information sharing (3), Technology (2), Introducing (2), Innovation (1), Homework (1), Activity (1), Practice (1), Material (1), Research (1), Sharing (1), Learning (1) As could be seen in the $1^{\text {st }}$ question, the concepts of "project, scientific study, discovery and invention" were the ones the students associated with what they understood from the concept of science fest. Whereas (1) numbered student who expressed what s/he understood from the concept of science fest mentioned that "Science fest is necessary. I would like to carry out and exhibit a project," (8) numbered 
student stated that "Science fest means to carry out a scientific research," and (23) number student used the expression of "... is a new invention," and (42) numbered student expressed his/her view as "... to be able to make new inventions."

$2^{\text {nd }}$ Question: Do you regard science fest at school as necessary? Why?

Key expressions and frequency values of the $2^{\text {nd }}$ question were as below:

Yes (45), Necessary (32), No (17), Creative (14), Project (11), Information Sharing (6), Innovation (6), Thinking differently (6), Invention (4), Didactic (4), Science (3), Ability (3), Technology (2), Learning (2), Discovery (2), Awareness (1) As could be seen in the answers of the $2^{\text {nd }}$ question, the students predominantly wrote the concepts of "yes, necessary, no, creative and project" on regarding the science fests as necessary. To the question of "Do you regard science fest necessary? Why?" whereas (3) numbered student answered that "Yes. It is a study that is especially necessary in history lessons. New ideas are suggested during the process of project designing, it provides us to think differently," (36) numbered student expressed his/her view as "Yes, it is necessary. The created products make history more entertaining and provide us to think differently," (61) numbered student told "Yes. It provides us to share our creativity and knowledge," and (42) numbered student stated that "No. ... Such projects are not more than being similar to each other in today's technological improvements."

$3^{\text {rd }}$ Question: What do you want to be included within the content of science fests? Why?

Key expressions and frequency values of the $3^{\text {rd }}$ question were as below:

Significant events and developments in our history (38), Models (28), Tools and equipment related to historical periods (15), Innovation (12), Computer programs (11), Project (11), Cultural elements (10), Awareness raising (9), Sports branches (5), Rules (4), Competition (3), Fantastic (1). As could be seen in the answers of the $3^{\text {rd }}$ question the students mostly wrote the expressions of "significant events and developments in our history, models, tools and equipment related to historical periods, and innovation" related to what they request to be included within the content of science fests. To the $3^{\text {rd }}$ question, whereas (5) numbered students expressed his ideas as "I want significant events and development in our history to be presented visually," (42) numbered student mentioned that "...developed models should be exhibited, innovation is necessary to be noticed by everyone, innovational studies should be carried out in history lessons," and (49) numbered student stated that "...creativity is essential, nothing should be repetitive, the exhibitions should be visited consciously."

$4^{\text {th }}$ Question: Are the science fests adequately regarded at schools? Please explain. Key expressions and frequency values of the $4^{\text {th }}$ question were as below:

No (37), Yes (29), Regarded (13), Disregarded (11), Compulsory (9), Not helping (8), Not much (8), There are responsive people (6), Not taken seriously (5), No planning (3). As could be seen in the answers of the $4^{\text {th }}$ question, students mostly used the expressions of "no, yes, regarded, disregarded and compulsory" for the situation of regarding the science fests at schools adequately. To the $4^{\text {th }}$ question asking whether science fests are regarded adequately at schools or not, whereas (27) numbered student answered that "No, only a few teachers are supporting, most of the teachers do not regard", (38) numbered student told that "Yes, it is regarded because some of our teachers told us that we are required to carry out," and (64) numbered students explained his view as "....not regarded much. Some of the projects are unplanned, and carried out without taken seriously."

$5^{\text {th }}$ Question: What do you recommend to the students who would like to participate into the science fests?

Key expressions and frequency values of the $5^{\text {th }}$ question were as below:

To be determined (41), To be creative (20), To work hard (15), To be a researcher (13), To have self-devotion (10), To be eager (10), To prepare a good project (6), To carry out a beneficial study (6), To be planned (2). As could be seen in the answers of the $5^{\text {th }}$ question, the students frequently used the expressions of "to be determined, to be creative, to work hard and to be a researcher" upon the recommendations for the students who wanted to participate into the science fests. To the question of what you recommend to the students who would like to participate into the science fests, whereas (9) numbered student answered as "...not possible without being determined. Because sometimes you do what you do again and again. It is necessary to study fearlessly," (16) numbered students stated that "You plan the subject you will prepare, you search it, and if you study devoting yourself, then you will be successful," and (56) numbered students expressed his view as "I was determined to manage, and I managed. I managed good work by the support of my family and teacher, you can also manage."

$6^{\text {th }}$ Question: Please explain what you understand from the concept of Project-based thinking.

Key expressions and frequency values of the $6^{\text {th }}$ question were as below:

New ideas (36), Invention (33), Creativity (19), Being original (14), Being a study of us (7), Technology (7), Learning 
(1). As could be seen in the answers of the $6^{\text {th }}$ question, the students were noticed to understand the concepts of "new ideas, invention, being creative and original" from the concept of project-based thinking. To the question asking students to explain what they understood from the concept of innovation, (25) numbered question answered as "to make original design through strengthening the current one with new ideas instead of rediscovering America," and (32) numbered student answered as "it means innovation, new ideas," (41) numbered student told "to make inventions of us."

$7^{\text {th }}$ Question: What project subjects on history lesson do you recommend to be carried out in science fests? Which do you prefer to carry out?

Key expressions and frequency values of the $7^{\text {th }}$ question were as below:

Life of the sultans (36), Ottoman history (25), Çanakkale War-Independence War (24), I prepared (20), Related to customs and traditions "Food culture-Marriage-Ceremonies-Clothing-Ornaments, etc." (14), Subjects comparing our history with the history of other countries (13), I recommend preparing on clothing (12), 3-dimensional materials should be prepared "Related to the history of civilization - Chinese-Sumerians-Egyptians-Aztecs-American Indian, etc." (9), History project (6), Preparation of videos and images (6), History of Islam (4), Clay tablets (2), Clothing of Janissaries (1), Clothing of Ninjas and our soldiers (1) As could be seen in the answers to the $7^{\text {th }}$ question related to their recommendation about the subjects of the projects to be carried out, and the project fields they carried out, the students were noticed to frequently focused on the subjects of "life of sultans, Ottoman history, Çanakkale War-Independence War, customs and traditions, comparisons with the history of other countries, and 3-dimensional materials." To the question asking whether they prepared an innovative study in science fests or not, (49) numbered student answered as "I prepared, I carried out a project upon the life of sultans," (66) numbered students told "...very good studies can be carried out upon Çanakkale War and War of Independence...," (58) numbered student expressed as "Comparing the history, customs and traditions of other countries with the history, customs and traditions of us is very enjoyable...," and (61) numbered students stated that “...I prepared 3-dimensional materials, it was very amusing, 3-dimensional materials should be used in lessons, as well."

$8^{\text {th }}$ Question: What do you recommend to be actualized in order to carry out innovation studies in science fests?

Key expressions and frequency values of the $8^{\text {th }}$ question were as below:

Plan (34), Research (26), Project (19), Receiving help from scientists (16), Brainstorming (9), Creativity (8), Originality (6), Imagination (5), Group work (4) As could be seen in the answers given to the $8^{\text {th }}$ question related to students' carrying out innovative studies in science fests, the students mostly used the expressions of "plan, research, project, and receiving help from the scientists." To the question of what the students recommend for carrying out innovative studies ins science fests, (26) numbered question answered as "a good study can be carried out receiving help of friends, teachers and academicians using imagination," (28) numbered student told "My teacher made a good plan, and I behaved in accordance with the progress of the project in each stage of the research," and (63) numbered student told his view as "It is essential to know the projects carried out before and to receive help from scientists in order to carry out an original study."

$9^{\text {th }}$ Question: What are the possible differences between the ones who participated into the science fests and who did not according to you? Why?

Key expressions and frequency values of the $9^{\text {th }}$ question were as below:

Much difference (39), Self-confidence (30), Imaginary world (24), Ambition (21), Knowledge (17), Idea "thought" (12), Self-reliance (8), Creativity (6), Regret (4). As could be seen in the answers to the $9^{\text {th }}$ question related to the difference between the students who participated and not participated into the science fests, the students were noticed to emphasize "much difference, self-confidence, imaginary world, ambition and knowledge." To the question asking the differences between the students who participated and not participated into the science fests, (33) numbered student answered that "My imagination, ambition, and knowledge has changed much since I participated into the science fests," (36) numbered student told that "Is it possible not to have difference? Is it possible to be the same for the one who carried out and the one who not?" and (44) numbered student expressed as "Science fests provides new ideas to be created, improve our imaginary world, and increase our knowledge."

$10^{\text {th }}$ Question: Does carrying our science fest projects in history lessons provide contribution upon the students' developing self-confidence? Why?

Key expressions and frequency values of the $10^{\text {th }}$ question were as below:

Yes (35), Increase at self-confidence (26), Experiencing the feeling of achievement (22), Provides contribution (14), Improvement at social intelligence (13), Increase at courage (7), Possible not to provide contribution (7), Creating the feeling of I can manage (4), due to the prejudice, possible not to have a positive effect (4), Not much difference (3), 
Possible to create disappointment (1). As could be seen in the answers given to the $\mathbf{1 0}^{\text {th }}$ question related to the fact that whether carrying out science fest projects in history lessons provided self-confidence in students or not, the students were noticed to mostly mention the concepts of "yes, self-confidence, it provides contribution." To the question of whether carrying our science fest projects provided contribution upon students' developing self-confidence or not, (2) numbered student answered as "Yes, It absolutely provides contribution. Primarily, our self-confidence improves, and our families trust us more," (14) numbered student mentioned that "Achieving made me happy, I had more self-confidence, I now have more courage upon carrying out more projects," and (57) numbered student stated that "Everything is good, achieving is very good, I can carry out more projects."

\section{$11^{\text {th }}$ Question: How did carrying out a project on history lesson affect your viewpoint to history? Why?}

Key expressions and frequency values of the $11^{\text {th }}$ question were as below:

I understood that history is not only memorizing (42), It affected positively (33), I used the information in books I have read (25), I understood that I can manage history (17), I understood that history is enjoyable (14), History lesson should be lectured benefiting from the projects (13), I noticed that we can use several modes-materials and equipment (11), It can be either boring or enjoyable depending upon teacher (9), I understood that I can also study out of school (6), I noticed that I cannot carry out a project on history (1). As could be seen in the answers given to the $11^{\text {th }}$ question related to whether carrying out a project affected their viewpoint to history, the students were noticed to mostly mentioned the expressions of "I understood that history is not only memorizing, it affected me positively, I used the information in the books I have read, I understood that I could manage history, I noticed that history is enjoyable, and history lesson should be lectured benefiting from the projects." To the question related to whether carrying out a project on history affected the viewpoint towards history lesson or not, (6) numbered student answered as "I love history lesson, but I used to get constantly bored of the monotone lecturing. In the projects, I noticed that history is not only memorizing, and is more efficient in this way. Students should definitely be provided to carry out projects on any area," (18) numbered student mentioned that "Noticing that I can achieve history affected me positively. It changed my viewpoint towards history," and (22) numbered student told that "Noticing that I can manage things on history made me happy. I had opportunity to use the knowledge I acquired in books."

\section{Conclusion}

Enhanced learning environments should be prepared to the students in order to encourage the sense of wonder. It is considered that learning will be more efficient through the research-based learning method that presents environments for the students providing them to learn through experiencing and practicing. The students with innovational ideas can create projects in history lessons, and present these innovative thoughts in science fests. The efficiency of this method was tried to be determined depending upon the findings obtained in the research. Students become aware of their own learning process through the project-based learning providing opportunities for the assessment of process the educational program predicts. In history lessons, development of creative thinking, adding new knowledge upon the old ones and putting the knowledge into practice are the fundamental purposes. For that reason, having no adequate studies upon the science fests on the basis of history lesson and not adequately using the individually innovative history projects in education have revealed the importance of this study. While getting prepared to the science fests, it has been aimed for the students to learn the subject as project-based during the process, use their creativity during the process of developing the project, and to be aware of their scientific process skills. This research was considered to be a sample for the individual innovation implementations in education and science fests in history lesson, and provide contribution for the literature.

The students were noticed to understand the concepts of "project, scientific study, discovery, and invention" most from the concept of science fest. Nearly all of the students were specified to regard the science fests in history lessons as necessary. A significant part of the students mentioned that science fests have not been considered as important adequately at schools. It was also mentioned that such studies should be especially supported. Mentioning that these studies were carried out by the support of a few teachers was another remarkable subject. The students were noticed to understand the concepts "new ideas, invention, creative and original" from the concept of project-based thinking. According to the students, the differences between the ones who participated and not participated into the science fests included participants' having more self-confidence, stronger imaginary world and more knowledge. Moreover, the students also mentioned that thoughts of the ones who participated into the science fests would develop more, their self-confidence would improve, and their creativity would be encouraged. The students specified that carrying out projects related to science fests in history lessons increased the self-confidence. Furthermore, it was also stated that the students would feel the sense of achievement, they would have more courage towards science, and they would have no more prejudice towards history. It was understood that students' carrying out projects on history positively affected their viewpoint to history. They especially mentioned that they got rid of memorizing, and using materials and equipment 
made the lesson more enjoyable. This proved that project-based studies could be carried out in history lessons. It was possible to mention that project-based lecturing should be increased more in history lessons, and science fests should be provided to be more functional. Carrying out such activities that would enhance the learning process of the students would make history lesson more enjoyable.

\section{References}

Ayan, M. (2012). Proje tabanlı öğrenme yaklaşımının ilköğretim öğrencilerinin fen bilgisi dersi akademik başarı düzeyine etkisi, Türk Eğitim Bilimleri Dergisi, 10(1), 167-183.

Balc1, A. (2005). Sosyal bilimlerde araştırma: yöntem teknik ve ilkeler, Ankara, Pegema Yayıncıllk.

Bayram, H., \& Seloni, Ş. R. (2009). Proje tabanlı öğrenme yaklaşımının ilköğretim 5. sınıf öğrencilerinin fen bilgisi başarılarına, kavramsal anlamalarına ve tutumlarına etkisi, Elementary Education Online, 8(1), 36-47.

Büyüköztürk vd. (2011). Bilimsel Araştırma Yöntemleri, Ankara: Pegem Akademi.

Çalışkan, H., \& Turan, R. (2008). Araştırmaya dayalı öğrenme yaklaşımının sosyal bilgiler dersinde akademik başarıya ve kalıcılık düzeyine etkisi, Türk Eğitim Bilimleri Dergisi, 6(4), 603-627.

Demirhan, C. (2002). Program geliştirmede proje tabanlı öğrenme yaklaşımı, Yayımlanmamış Yüksek Lisans Tezi, Ankara: Hacettepe Üniversitesi Sosyal Bilimler Enstitüsü.

Helle, L., Tynjälä, P., \& Olkinuora, E. (2006). Project-based learning in postsecondary education - theory, practice and rubber sling shots, Higher Education, 51(2), 287-314. http://dx.doi.org/10.1007/s10734-004-6386-5

Karasar (2009). Bilimsel araştırma yöntemleri, Ankara: Nobel Yayınları.

Kavacık, L. (2012). İlköğretim 6. sinıf fen ve teknoloji dersi madde ve isl ünitesinde grupla yenilikçi (inovasyon) projeler oluşturmanın ögrrenciler üzerindeki etkileri, Yayımlanmamış Yüksek Lisans Tezi, Mersin Üniversitesi Eğitim Bilimleri Enstitüsü.

Liu, W. L., Wang, C. K. J., Tan, S. T., Coh, C., \& Ee, J. (2009). A self-determination approach to understanding students' motivation in project work. Learning and Individual Differences, 19(1), 139-145. http://dx.doi.org/10.1016/j.lindif.2008.07.002

MEB. (2007). Millî Ĕ̆itim Bakanlı̆̆ Talim ve Terbiye Kurulu Başkanlı̆̆ı ortaöğretim 9. sınıf tarih dersi programı, Ankara: Milli Eğitim Basımevi

Metin, M. (2014). Kuramdan uygulamaya eğitimde bilimsel araştırma yöntemleri, Ankara: Pegem Yayıncılık.

Miles, M. B., \& Huberman, A. M. (1994). Nitel veri analizi (2nd edition). Thousand Oaks, CA: Sage Publications.

Özden, M., Aydın, M., Erdem, A., \& Ekmekçi, S. (2009). Öğretmenlerin proje tabanlı fen öğretimi konusunda görüşlerinin değerlendirilmesi, Elektronik Sosyal Bilimler Dergisi, 8(30), 92-102.

Yıldırım, A., \& Şimşek, H. (2008). Nitel araştırma yöntemleri, Ankara: Seçkin Yayıncılık.

www.fenokulu.net (20.11.2015).

\section{$(\mathrm{Cc}) \mathrm{BY}$}

This work is licensed under a Creative Commons Attribution 3.0 License. 